\title{
83 will the real sex slave please stand up?
}

\author{
Julia O'Connell Davidson
}

\section{abstract}

This paper critically explores the way in which 'trafficking' has been framed as a problem involving organized criminals and 'sex slaves', noting that this approach obscures both the relationship between migration policy and 'trafficking', and that between prostitution policy and forced labour in the sex sector. Focusing on the UK, it argues that far from representing a step forward in terms of securing rights and protections for those who are subject to exploitative employment relations and poor working conditions in the sex trade, the current policy emphasis on sex slaves and 'victims of trafficking' limits the state's obligations towards them.

\section{keywords}

trafficking; sexual slavery; sex work; forced labour; irregular migration 


\section{will the real sex slave please stand up?}

Over the past decade, a range of governmental and non-governmental actors have displayed growing awareness of, and concern about, the fact that the sex industry can be a site of various (and sometimes extreme) forms of exploitation and abuse. Within this, particular concern has been focused upon phenomena described as 'sexual slavery' and as 'trafficking for sexual exploitation', and in dominant anti-trafficking discourse, two assertions have been so repeatedly made that they have acquired an almost mantra-like quality. The first is that human trafficking is taking place on a massive scale everywhere. Trafficking is described as 'a $\$ 7$ billion a year business' involving tens of thousands of women and children annually: 'No one now disputes that trafficking today has reached alarming proportions, the magnitude of which affects many countries as countries of origin, transit and destination points' (Javate de Dios, 2002: 1). The second is that trafficked persons are victims of modern slavery and should be treated as such, a statement that is now as likely to be made by government ministers as it is by spokespeople for Non-Governmental Organizations (NGOs) that lobby on the issue.

Given the undisputed and alarming magnitude of the phenomenon, and the fact that for at least the past five years, many international agencies and governments have given high priority and devoted extensive resources to combating the problem, it is puzzling to find that the number of people who have been identified as 'victims of trafficking' (VoTs) and assisted as such is very small. The UK is a case in point. In 2000, a Home Office report estimated that every year, anywhere between 140 and 1400 women and girls were being trafficked into prostitution in Britain, and recommended that the police should pay particular attention to off-street prostitution where trafficked women and girls were especially likely to be held (Kelly and Regan, 2000). New legislation has subsequently been introduced to tackle this supposedly growing phenomenon, a special Home Office funded project (the Poppy Project) has been set up to support VoTs, and various police forces have worked closely with the immigration authorities to identify and rescue women trafficked into the sex industry. However, if those involved in designing and implementing these measures were sincere in their belief that hundreds of women were annually being trafficked into Britain for purposes of sexual exploitation and in their desire to assist them, they must surely be disappointed by the results.

In 2003, the London Metropolitan Police Clubs and Vice Unit and immigration service officers found 295 immigration offenders in the course of regular routine visits to massage parlours and saunas in London, of whom only four or five were identified as VoTs and referred to the Poppy project. The rest were deported (or 'administratively removed', in UK immigration service-speak). In the same year, the Poppy project also received the grand total of 15 referrals from other 
agencies, and had in all 24 women in their facilities. Raids on indoor prostitution establishments in other areas have yielded similarly low numbers of VoTs. Upon contact with the authorities, the huge and growing numbers of trafficking victims in need of protection have a habit of transmogrifying into 'illegal immigrants' who must be summarily deported. For undocumented migrants in the sex sector, being identified as potentially vulnerable to abuse and exploitation often appears to mean exposure to additional risks rather than an opportunity to access rights and protections. And more generally it seems that despite the extensive attention paid to rights violations in the sex industry and a raft of new international protocols and declarations, national laws, and policy initiatives designed to combat such abuses, very little progress has been made in terms of promoting or protecting the human or labour rights of those who prostitute.

This paper explores the relationship between this lack of progress and the current policy emphasis on sex slaves and trafficking victims. It draws on on-going ESRCfunded research ${ }^{1}$ and focuses primarily on the UK, though the same basic argument could be made in relation to policy and practice in many other countries.

\section{slavery, modern slavery and trafficking}

To describe human trafficking as 'nothing less than modern day slavery', as UK Solicitor General Harriet Harman recently did (AntiSlavery International, 2005), is a powerful piece of rhetoric. Taken literally, however, it brings us onto difficult philosophical and political terrain, for scholars have always struggled to cleanly demarcate autonomy and slavery, and free and unfree labour, as oppositional categories (Brace, 2004). The problem is that even when understood as defined in the Slavery Convention of the League of Nations (1926), which states that slavery is 'the status or condition of a person over whom any or all of the powers attaching to the right of ownership are exercised', slavery implies a package of unfreedoms, not all of which are unique to slavery. Some of the powers attaching to the right of ownership can be and often are also exercised over groups that are not socially imagined as 'slaves', such as wives, children, employees, and professional athletes (Patterson, 1982; Brace, 2004; 0'Connell Davidson, 2005). Certainly, if we are concerned with slavery as a form of labour exploitation, there is no clear line between it and 'free' wage labour. Slavery has always stood at one pole of a continuum of exploitation, shading off into servitude and other forms of exploitation, rather than existing as a wholly separate, isolated phenomenon (Lott, 1998).

The quest for a sharp line between slavery and freedom persists in contemporary accounts of 'modern slavery', however. So, for example, in his book Disposable People: New Slavery in the Global Economy, Kevin Bales begins by noting that
1 The study focuses on the markets for migrant domestic and sex workers in the UK and Spain, and includes interview research with those who own or manage sex sector establishments and indirectly employ migrant sex workers, as well as with individuals who buy sex. 
'New Slavery' is a phenomenon quite separate from other forms of oppression and labour exploitation:

Having just enough money to get by, receiving wages that barely keep you alive, may be called wage slavery, but it is not slavery. Sharecroppers have a hard life, but they are not slaves. Child labour is terrible, but it is not necessarily slavery.

(Bales, 2000: 5)

New Slavery, according to Bales, also differs from what has traditionally been understood as slavery in a number of senses. It is not a condition that is linked to an excluded legal or political status, it does not necessarily entail natal alienation, it is not a permanent condition, ethnic differences are not relevant to the New Slavery, and the New Slavery is not a feature of a different or separate 'mode of production' - surplus is extracted from the New Slave's labour in essentially the same way that it is extracted from non-Slaves. For Bales, the New Slavery is part of a shadowy, unregulated economic realm in which people can be treated as 'completely disposable tools for making money' (2000: 4). It is the dark and lawless underside of globalization. And because it is impossible to distinguish New Slaves from wage slaves either through reference to their legal or social status, or to the way in which surplus is appropriated by a dominant class, Bales is left insisting that New Slavery differs from wage slavery because it is about 'the total control of one person by another for the purpose of economic exploitation' (2000: 6, emphasis added). No matter how hard the life of wage slaves, they are not completely controlled by another person. The wage slave can, by implication, make choices.

This notion of 'total control' is a fragile hook on which to hang the concept of slavery. In fact, using this definition, many 'Old Slaves' would not count as 'New Slaves' - not all slaves in slave societies of the Caribbean and America, for instance, were completely controlled by their legal owners - some were in a position to engage in a autonomous trading (including the trade of sexual services), and/or to engage in a range of different types of resistance (Beckles, 1989; Lott, 1998; Geary, 2004). And setting up an opposition between 'total control' and 'choice' begs the question of how much choice, and choices between what? If debt - either real or fictional - is used as the means to control a worker, is this complete control or does the debtor have a choice about whether or not to comply with the demands of the person $s /$ he is indebted to? Does an opportunity to quit represent a 'choice' even when it carries with it a risk of being reported to the immigration authorities and deported?

A similar set of philosophical and definitional problems surround the concept of 'trafficking', and boundary disputes are all the more heated because different agencies and groups identify trafficking as a problem for very different reasons and have very different political agendas with regard to the issue. While governments' interest in trafficking is primarily grounded in concerns about irregular immigration 
and transnational organized crime, human rights NGOs' interest in the phenomenon is often based in broader concerns about 'modern slavery' as defined above. Meanwhile, feminist abolitionist groups such as Coalition Against Trafficking in Women (CATW) view trafficking as central to, and emblematic of, the increasing globalization of female sexual exploitation (Raymond, 2001). Feminist abolitionists hold that it is impossible for women to consent to prostitute, since prostitution dehumanizes and objectifies women. Prostitution is therefore a form of slavery, and since nobody can elect to be a slave, all prostitutes have been trafficked into their condition (Barry, 1995; Jeffreys, 1997).

Until recently, there was no international agreement as to the proper legal definition of trafficking. Following much debate between those with a political stake in the issue, in November 2000, the UN Convention Against Transnational Organized Crime was adopted by the UN General Assembly, and with it two new protocols, one on smuggling of migrants and one on trafficking in persons - the Protocol to Prevent, Suppress and Punish Trafficking in Persons, Especially Women and Children. In the latter, trafficking is defined as:

The recruitment, transportation, transfer, harbouring or receipt of persons, by means of the threat or use of force or other forms of coercion, of abduction, of fraud, of deception, of the abuse of power or of a position of vulnerability or of the giving or receiving of payments or benefits to achieve the consent of a person having control over another person, for the purpose of exploitation. Exploitation shall include, at a minimum, the exploitation of the prostitution of others or other forms of sexual exploitation, forced labour or services, slavery or practices similar to slavery, servitude or the removal of organs.

The Protocol is held to have redefined the international standard of trafficking in the sense that it allows for the possibility that people may be trafficked for purposes other than exploitation in prostitution, and it is further said to 'establish new standards with respect to protecting the rights of trafficked persons' (Pearson, 2002: 16). The Trafficking Protocol entered into force in December 2003. By 2004, it had been signed by 117 countries, many countries had made efforts to bring their national laws in line with it, and all governments are being urged to do so not only by supranational political bodies such as the Council of Europe, but also by both feminist abolitionist and human rights NGOs involved in anti-trafficking campaigns.

At the same time, however, the Trafficking Protocol has been subject to extensive critique. The Protocol definition of the term 'trafficking' does not describe a single, unitary act leading to one specific outcome, but rather refers to a process (recruitment, transportation and control) that can be organized in a variety of ways and involve a range of different actions and outcomes. Trafficking, like traditional understandings of slavery, comes as a package, and there is room for dispute as to which particular actions and outcomes, and in what particular 
combination, should be included under its umbrella. This problem is compounded by the fact that many of the constituent elements identified in the Protocol definition of trafficking themselves present definitional problems (there is, for example, no international consensus regarding the definition of 'sexual exploitation', or indeed of 'exploitation'), and by the fact that the abuses that come under the umbrella of 'trafficking' can vary in severity, generating a continuum of experience rather than a simple either/or dichotomy (Anderson and 0'Connell Davidson, 2002).

Of particular relevance for this paper, the fact that the Protocol is framed within the Convention on Transnational Organized Crime, and packaged with a Protocol on smuggling, reflects a preoccupation with 'illegal immigration' as part and parcel of a supposed security threat posed by transnational organized crime as opposed to a concern with the human rights of migrants (see Beare, 1999; AMC, 2000; Anderson and 0'Connell Davidson, 2002; Kapur, 2005). Taken together, the trafficking and smuggling protocols assume a neat line of demarcation between oppositional categories of migration - voluntary and consensual versus involuntary and non-consensual migration - an assumption that research shows to vastly oversimplify the systems and processes that facilitate irregular migration in the real world, and fails to recognize the complexity and variety of social relations between irregular migrants and those who benefit directly or indirectly from their exploitation (see, for instance, Parrenas, 2001; Agustín, 2002; King, 2002; Andrijasevic, 2003; Lutz, 2004). And crucially, the Trafficking Protocol is problematic from a human and migrants' rights perspective because it attaches special significance to situations in which abuses at the point of destination are linked to the use of force or deception within the migration process. State Parties are not being required to meet new and higher standards with respect to protecting the rights of any migrant person who is subject to deception, force and exploitation within their borders, but only with respect to those who have also been cheated and exploited within the migratory process.

This latter problem was implicitly recognized in the report of an Experts Group on Trafficking in Human Beings convened by the European Union in 2003, which actually notes that forced labour is the crucial element of the Protocol, and states that 'policy interventions should focus on the forced labour and services, including forced sexual services, slavery and slavery-like outcomes of trafficking - no matter how people arrive in these conditions - rather than (or in addition to) the mechanisms of trafficking itself' (European Commission, 2004: 53). Welcome as this statement is, it does not entirely resolve the problems mentioned above. The concept of 'forced labour' itself presents definitional problems (see Anderson and Rogaly, 2005). Indeed, as the International Labour Office (2005: 8) recent report on forced labour in the global economy acknowledges, 'the line dividing forced labour in the strict legal sense of the term from extremely poor working conditions can at times be very difficult to 
distinguish'. And even if such definitional problems could be resolved, the Trafficking Protocol would remain a highly selective instrument with which to address the general problem of forced labour because, framed as it is within a Convention on transnational organized crime, the interventions that flow from the Protocol are necessarily only triggered by immigration offences and/or organized criminal activity. As argued below, this means they inevitably focus on an extremely limited and narrow part of the problem.

\section{to catch a victim?}

I was recently asked to speak at a conference on trafficking. In the e-mail of invitation, the Conference Producer told me that he was 'very keen to have at least one presentation on the issue of what happens to the victims of trafficking once they have been caught by the authorities'. Doubtless the words were not intentionally chosen, but nevertheless, I felt this mixture of language, the idea of catching victims, spoke volumes about the limitations of dominant antitrafficking discourse from a human rights perspective. Framed as a crime control and prevention issue, 'trafficking' has been presented as a phenomenon orchestrated by ruthless, transnational organized criminal networks. This not only makes it possible for governments to present measures to prevent irregular forms of migration as though they were simultaneously anti-trafficking measures, but also means that the authorities charged with a responsibility to contain illegal migration and combat organized crime are simultaneously deemed to be frontline actors as regards rescuing VoTs. It is implicitly, sometimes explicitly, assumed that by casting a net to catch immigration offenders and individuals involved in a specific set of criminal activities such as those associated with prostitution, drug running, and people smuggling/trafficking, the authorities will also catch victims.

Leaving aside, for the moment, the problems and conflicts of interests that may arise when police and immigration officials are expected to catch offenders and victims, it is important to note that the waters fished by these actors are extremely limited. The package of violations covered by the UN Protocol definition of 'trafficking' (violence, confinement, coercion, deception and exploitation) can and do occur within legally regulated as well as irregular systems of migration and employment, and within legal as well as illegal systems of migration into private households. (For some extremely disturbing examples of forced labour involving migrant workers who entered the UK through perfectly legal channels and were legally employed in the formal economy, including in the public sector, see Anderson and Rogaly, 2005). And yet migrants who have been subject to abuse and exploitation within legal systems of migration are not likely to be caught by police or immigration officials. Indeed, for migrant workers in most sectors in the UK, there is no authority vested with the duty and power to check that they are not being exploited, and if they are, to discover whether their exploitation is linked to the use of force, debt or deception within the migration process. 
Although the UN Protocol is often praised for having broadened the international definition of trafficking such that people moved for purposes other than exploitation in prostitution can now be recognized as VoTs, in practice, the sex sector still remains the primary focus of most countries' 'anti-trafficking' efforts. However, identifying VoTs in the sex sector requires the authorities to distinguish between forced labour and extremely poor working conditions, and this is no easy task. Before looking at how police and immigration officials in the UK imagine this distinction, I will briefly illustrate the extent of the problem with examples of employment relations and working conditions in just one form of prostitution in one city, London.

\section{the spectrum of working conditions and employment relations in 'working flats' in London}

In November 2005, Gavril Dulghieru, a Moldovan living in London, was convicted for conspiracy to facilitate illegal immigration, misuse of stolen credit cards, forgery, money laundering and conspiracy to traffic for prostitution and sexual exploitation. The women he trafficked worked 20-hour shifts in brothels in Park Lane, Mayfair and Soho, were fed only one meal a day, and charged for the use of cutlery:

They were forced to have sex with up to 40 men a day for as little as $£ 10$ a time to pay off $£ 20,000$ debts each - the price for which they were 'bought'. They were charged rent, and subjected to fines if they refused anal or unprotected sex or a client was not attracted to them... One 23-year-old described how she had to pay $£ 300$ per day to live locked in a shared basement and her captors threatened to kill her family. Like many trafficking victims, the computer graduate was lured to Britain by promises of a respectable, well-paid job in a hotel or restaurant but ended up in a brothel: 'I believed they would kill my family,' she told the court. 'I thought I hadn't a way out of this situation. I didn't think I had a life in front of me. I wanted to escape but everything was locked. We were locked up all the time. I was told I need to go with clients and I needed to do sex with them. I felt very bad. The first time I wasn't able to talk afterwards'.

(Cowan, 2005)

The 23-year-old quoted above conforms closely to popular understandings and images of a VoT. She was tricked into travelling to the UK with the promise of 'respectable' work, she was locked into a building and forced (both through the use of death threats against her family and through demands to repay a debt) to provide sexual services, and she was psychologically devastated by the experience. 
A second example of working conditions and employment relations comes from an interview with a woman, 'Pat', a former sex worker who runs three 'walk up' brothels or flats in Soho, indirectly employing nine sex workers, only one of whom is a British national. Pat does not actively recruit workers either in the UK or abroad, and so has no involvement in facilitating or arranging the migration of the sex workers she employs. Instead, women looking for work (who may or may not be acting under duress from third parties who arranged their migration) telephone or knock on the door and ask to be taken onto her books. The flats are open for business 24 hours per day, every day of the year except Christmas Day and New Year's Day, and the sex workers work 12-hour shifts on a roster system. Only one woman at a time works in each of the flats, which means that on average, every worker on Pat's books takes on between four and five shifts per week, and so works for somewhere between 48 and 60 hours per week. As it is illegal to directly employ a sex worker, Pat's workers do not receive a set wage per shift. Instead, they are required to pay Pat $£ 350$ for every shift they work - a sum which in theory pays for the rental of workspace plus other services supplied by Pat (advertising the brothel, employing a maid to take phone calls and clean the flat, provision of food, tea and coffee, also items necessary to their work such as tissues, clean sheets, uniforms, and finally safety precautions such as CCTV).

However, while the relationship between Pat and the sex worker is, in this sense, constructed as a contract between two independent entrepreneurs rather than an employment relation, it is Pat who sets the rates for services and lays down rules concerning working practices, and so, in effect, exerts close control over their work rate. Walk up brothels in Soho cater primarily to the demand for cheap, quick sexual services. Pat's pricing system, which is based on extremely short time units, reflects this. The cheapest service available at $£ 20$ is either penetrative sex in the missionary position or oral sex for 10 minutes. If the client wants both penetrative and oral sex in his 10 -minute slot, it will cost him $£ 25$; if he wants oral sex plus penetrative sex in a position other than missionary, it will cost him $£ 30$. The next time unit is 15 minutes, then 20 minutes, then 30 minutes, and then to the highest possible unit, 1 hour, which costs $£ 120$ for oral and penetrative sex. Anal sex costs an additional $£ 100$, and the prices for oral sex without a condom, and for ejaculating over the worker's breasts or body are also much higher $(£ 140)$ regardless of the unit of time.

If all the clients that arrived during a shift were to ask for the cheapest service, then in order to pay Pat the shift fee of $£ 350$, a worker would need to service 18 clients before even beginning to earn for herself. And if she continued on to service a further 17 clients, she would - like Gavril Dulghieru's forced prostitutes - in effect be having sex with a large number of men for as little as $£ 10$ a time. In practice, many clients do ask for more expensive services, and/or can be persuaded to spend more on extras, and sex workers rely in particular upon regular customers who tend to spend longer with them and request more 
expensive services. Indeed, Pat claims that during a 12-hour shift, workers regularly gross $£ 700$, so that they usually take home $£ 350$ per day. And yet it is clearly the case that her workers could, on bad days, experience a strong financial pressure to engage in acts that they might otherwise refuse, and that potentially carry serious health risks, such as anal sex, or oral sex without a condom.

As we only interviewed Pat, and not any of her workers, it is not possible to say whether any of the migrants she indirectly employs are working to pay off debts incurred during the process of migration, but other research with migrant women working in the sex industry suggests that it is likely that some are (see Andrijasevic, 2003; Agustín, 2005, for example). The need to repay such debt, especially if combined with the pressure to pay for accommodation in London, and to support dependants back home, could thus operate as strong pressure to continue to work for Pat, also to accept a volume of clients and to provide services that the worker would not otherwise agree to.

A third example comes from an interview with 'Ava', another former sex worker who runs a 'working flat' in the East End of London, and offers indirect employment to 11 sex workers, six of whom are British nationals. The flat is open between 11 am and 10 pm, and each day, two sex workers work the 11-hour shift together. Ava does not, therefore, offer full time employment to the women who work for her (though they may end up working as many hours per week as Pat's workers, since some of them are also indirectly employed in other working flats or massage parlours). Like Pat, Ava does not actively recruit workers - women approach her for work - but as noted in relation to Pat, it is possible that the non-British nationals she employs are working to pay off debts to third parties who arranged their migration. However, if this were the case, the women concerned would not be exposed to the same degree of exploitation as those who work for Pat. Ava provides all the services that Pat provides her workers, but does not charge them a session fee for so doing. Instead, each worker's takings are split equally between Ava and the worker. This means that the worker is not forced to shoulder the cost when trade is slow, and it is not possible for a worker to end up owing money to the house at the end of a session, as it is in establishments that operate the session fee system. Ava sets the prices for services, and they are set at a similar level to those in Pat's Soho walk up. However, unlike at Pat's, there is no 10-minute fee and the price structure and employment relation is not designed to encourage a high throughput of low price trade.

Ava's 'house rules' are also distinctive, leading to different working practices. Ava does not permit her workers to provide any services without condoms, indeed, this rule is important to the way in which she markets her flat in her internet advertising as a clean, safe place to buy sexual services. Furthermore, she actively encourages those who work for her to refuse to provide services that 
they do not feel comfortable about providing. She explained that she tells workers that it is wrong to assume that they will lose business if they do not agree to anything and everything clients request, saying:

If anything, it's the other way around, the less you offer, the busier you can be. There's the safety aspect of it, and also the fact that then the guys can look at you and think, 'Well, what she does offer, she must like, because she feels free not to offer what she doesn't like'.

Ava does not have a high turnover of staff. In fact, several of the women who work for her have been with her for a number of years, something that doubtless testifies to the fact that the working conditions and earnings opportunities she provides are good relative to other similar establishments.

\section{will the real sex slave please stand up?}

Feminist abolitionist groups like CATW have lobbied very effectively in national and international policy-making circles to get 'sex trafficking' onto the political agenda as a huge and growing problem, and one that involves the enslavement and torture of 'prostituted' women and girls. The campaigning materials they produce reflect their vision of 'the prostitute' as object, victim and slave. They feature graphic depictions of the violence and harm associated with 'the rapelike sex acts of prostitution' (Hughes 2000: 3) - testimony from women and girls who have been violently beaten and raped by pimps, and/or tortured by sadistic clients, lists of physical illnesses and psychological conditions suffered by women in prostitution, images of trafficked women as puppet-like objects or slabs of meat, or even as decapitated heads packaged as sex toys. These images of 'bodies in pain: pierced, bleeding and defenceless' have been reproduced in antitrafficking materials created by more mainstream organizations, such as the International Organization for Migration and the Organization for Security and Cooperation in Europe, and in government information and awareness campaigns on trafficking (Aradau, 2004: 264).

However, where members of CATW and other feminist abolitionists consider that it is impossible for a woman to consent to sell sexual services, and that all migrant women in prostitution (indeed, all female prostitutes, whether migrant or not) are therefore VoTs deserving of protection and assistance, politicians and policymakers tend to be rather more selective in their view of who is and is not a sex slave. In most countries, to stand any chance of being identified and assisted as a VoT by the authorities, a migrant woman or girl working in the sex trade needs to demonstrate first that she did not choose or consent to work in prostitution, and second that she has undergone great physical suffering. In the US, for example, the Trafficking Victims Protection Act of 2000 makes various forms of protection available to victims of 'severe forms of trafficking', but access to 
these protections is restricted, and 'relies heavily on the distinction between 'innocent victims' of forced prostitution and 'guilty sex workers' who had foreknowledge of the fact they would be performing sexual labor' (Pearson, 2002; see also Chapkis, 2005: 57-58).

This distinction has much wider currency (Doezema, 1999, 2002; Harrington, 2005). And even where the law does not rule out the possibility that a woman could have agreed to migrate into sex work but subsequently found herself exploited and unable to escape her situation, the status of VoT is by no means automatically given to those who have been subject to the abuses listed as constitutive of 'trafficking' in the UN Protocol. Instead, to be recognized as a VoT, they will need to demonstrate that they have been subject to very specific types of abuse, in particular to rape and/or other forms of extreme physical force. The UK is a case in point. The Asylum and Immigration Bill 2004 states that a person who facilitates travel to or within the UK is guilty of the criminal offence of trafficking if an individual so facilitated: 'is the victim of behaviour that contravenes Article 4 of the Human Rights Convention (slavery and forced labour)', or 'is subjected to force, threats or deception designed to induce him (i) to provide services of any kind; (ii) to provide another person with benefits of any kind, or; (iii) to enable another person to acquire benefits of any kind'. However, since the legislation, like the UN Trafficking Protocol, fails to provide clear guidelines on the degree of deceit, the type and degree of force, or the type of threats that must be present in order for a person to qualify as a VoT, police and immigration officers must use their judgement to decide whether women and girls picked up during routine visits and raids are or are not VoTs.

Our preliminary interviews with police and immigration officers in the UK suggest that upon contact with the authorities, women need to immediately report a very particular set of experiences to qualify as a VoT. For instance, asked how she could tell if someone picked up during a raid on a massage parlour was or was not a VoT, an immigration officer answered that during their initial interview (which is usually very brief and held in an interview room in a police station), women are questioned about their routing on the way to the UK, whether they knew what kind of work they would be undertaking, whether they had worked in the sex trade back home, and whether an agent was involved in their migration into sex work in UK. And:

If they say that they were brought here against their will, or they were sold from prostitution in one country on to prostitution in another, or that they're not allowed to leave the building or that they aren't given food, that would obviously tell you they were trafficked.

Likewise, an officer from the Metropolitan Police vice unit explained to me that in his experience, the majority of migrant sex workers in indoor forms of prostitution in London are economically exploited by the owners of such establishments; many have been deceived about earnings and working conditions; and most are working 
to pay off debts incurred in migration. However, he continued, very few are forced and controlled through means of physical violence or its threat, and it is only rarely that indoor sex establishments are actually run by the same person or people who have recruited the women and/or arranged their entry into the country. In his view, it follows that very few are VoTs. The fact that police and immigration officers in the UK are looking for a very specific constellation of abuses, namely one involving conspiracy to facilitate illegal immigration, plus prostitution forced by means of physical violence or its threat, plus false imprisonment, is further demonstrated by events surrounding a recent raid on a massage parlour in Birmingham. In October 2005, police executed a human trafficking warrant in a massage parlour (named Cuddles) in order to rescue a number of foreign nationals who were believed to be subject to forced prostitution therein. Police and immigration officers removed 19 women from the parlour. Those who could prove that they were legally present in the UK (most of whom were Lithuanian, and so EU citizens) were then released. The conditions under which they were working in Cuddles were not investigated further. The six who could not prove they were legally present in the country were detained and asked, in interviews conducted by male officers and lasting in some cases a mere 17 minutes, how they had travelled to the UK, and how they came to be working in Cuddles. On the basis of their answers, the officers involved decided that they were not VoTs, and two days later, they were transferred to an immigration detention centre to await 'removal'.

Claudia Aradau has observed that the images of bodies in pain routinely used in anti-trafficking campaigns function:

'as a strategy of dis-identification... As trafficked women have been subject to cruelty, their undeniable suffering at the hands of traffickers makes them extraordinary, beyond ordinary identifications with illegal migrants and prostitutes. Where their trajectory might have coincided with that of a migrant or prostitute, suffering is redeeming. Trafficked women are dis-identified from categories of migrants, criminals or prostitutes by the emphasis on raw physical suffering'

(Aradau, 2004: 257)

Likewise, it seems that physical suffering is the litmus test for police officers and immigration officials involved in sorting VoTs from undocumented migrants working illegally in the sex sector. The threshold of 'victimhood' is, in other words, set very high, and who is going to question this threshold? Not governments that currently place a high priority on being seen to be tough on immigration. And the NGOs that are most vocal in anti-trafficking campaigns are hostages to their own rhetoric. Feminist abolitionists have insisted that violence is an inevitable and ubiquitous feature of the 'sexual slavery' that is prostitution (Weitzer, 2005) and have called on governments to act against 'sex trafficking' on grounds that migrant women and girls in prostitution are routinely subjected to rape, beatings,
2 All six would have been 'removed' four days later had it not been for extensive lobbying with regard to their case.

Eventually, the six were interviewed by Poppy Project workers, who identified two of their number as VoTs. 
imprisonment and torture. They are thus hardly in a position to challenge governments to lower the threshold of victimhood. Indeed, the immigration official or police officer who has read nothing about prostitution save the horror stories that are presented as typical by groups such as CATW (stories featuring girls locked in filthy rooms and variously burned with cigarettes, slashed with razor blades, whipped, punched, drugged, etc., etc.) may perhaps be forgiven for assuming that where there is no evidence of this type of physical assault, no rights violations have taken place. Equally, anti-slavery campaigners who define modern slavery as a condition in which a person is totally controlled by another person are not well placed to challenge the authorities to work with more complex readings of terms like 'force', 'deception', 'coercion' or 'exploitation'.

\section{the opposite of sex slavery?}

Feminist abolitionists are emphatic that all prostitution is sexual slavery. This form of modern slavery has no opposite in the shape of freely chosen sex work. It follows that the victim of sex slavery cannot alter her status as victim and slave by successfully struggling for recognition of her human, civil or labour rights within the sex industry, only by being rescued or freed from her condition as a prostitute. This position has been subject to extensive and powerful critique by other feminist scholars and activists who emphasize women's capacity and right to act as moral agents within prostitution, and who argue that abuse and exploitation in the sex sector is intimately connected to the fact that sex workers are rarely afforded the civil and labour rights enjoyed by other citizens and workers (Alexander, 1997; Bindman, 1997; Chapkis, 1997; Nagle, 1997; Kempadoo and Doezema, 1998; Kempadoo, 1999).

But international policy debate on 'trafficking' and forced labour in the sex sector is not generally informed by a vision of what might constitute the opposite of sex slavery. This is partly because human and child rights NGOs that actively lobby on the issue, as well as many politicians, often assume that the dispute between abolitionists and sex workers' rights activists can simply be left to one side while the real problem is discussed (the idea being that everyone can agree that sexual slavery is wrong, and we should therefore focus on this area of consensus rather than being drawn into an apparently insoluble moral and political debate about prostitution). It is also because religiously inspired and feminist abolitionists together comprise a very economically and politically powerful lobby, one that few can afford to offend. So, for example, the ILO's recent report on forced labour mentioned earlier discusses 'trafficking and forced sexual exploitation' and not forced labour in the sex sector, and focuses heavily upon the situation of those women and girls who have been deceived into prostitution and on the role of 'powerful organized crime groups' in controlling the sex industry and orchestrating 'human trafficking' (ILO, 2005: 52). Indeed, though the report estimates that 'forced commercial sexual exploitation' 
represents 11 per cent of cases of forced labour in the contemporary world, and contains much that might be relevant to efforts to secure basic human rights for those working in the most exploitative segments of the sex industry, it does not subject the sex sector to the same kind of analysis as that applied to other sectors. This, it may be assumed, is because the ILO needs US funding to develop its global alliance against forced labour, and such funding would not be forthcoming were the ILO to so much as use the term 'sex work', let alone sketch out a vision of how best to protect sex workers as workers.

Meanwhile, in the UK, the Government's recent review of prostitution (Home Office, 2004, 2005) spoke only to the condition of children, young people, and drug users in prostitution, and those forced to prostitute through the use of physical violence. Other than some recent hints that it may consider measures to allow two or three sex workers to work together in indoor prostitution, the Government has entirely failed to address the situation of those women and men who do regard prostitution as a form of work and whose vulnerability, where it exists, arises precisely because they are denied rights and protections as workers under existing prostitution law, and in the case of undocumented migrants, because of their irregular immigration status.

In short, 'sex slavery' has come to the fore of policy attention, but its opposite in the form of prostitution as work remains largely invisible. In commenting on this, I do not wish to suggest that the rights of those who sell sex can be assured and protected by simply bringing the sex industry above ground and regulating it like any other sector. Indeed, there is no reason to suppose that merely extending existing labour law to cover sex work would automatically safeguard the interests of the most vulnerable workers - see Blackett's (1998: 1) analysis of how, despite their inclusion under general forms of labour regulation in most countries, domestic workers 'remain fundamentally invisible', because most legislative enactments and agreed labour standards do not address the specificity of the employment relationship between domestic worker and employer. And so far as domestic work is concerned, additional problems arise from the fact that employers are often interested in migrants because they are 'less demanding, more flexible concerning working hours'; that migrant domestic workers are often in a 'precarious position because of insecure legal status in the host country'; that for many women, domestic work is often the only way to find employment abroad and to escape poverty in their own country; and that 'unionization of domestic workers is fraught with obstacles' (ILO, 2005: 50-51). These points are also relevant to the sex sector, and highlight very real dilemmas as regards calls for closer state regulation of that sector. For many migrants who trade sex, becoming visible is more likely to mean being deported than it is to mean securing rights and protections as workers.

Some sex workers' rights activists hold that such problems could be solved by granting prostitutes 'the right to travel across state and national boundaries and 
3 It is also worth noting that some people who prostitute actively wish to live and work in a world outside civil society, untrammelled by state controls and bureaucratic regulations, and entirely free to make individual decisions about the kind of contracts they enter into. Such people may be in favour of decriminalising prostitution, but would not necessarily wish to find themselves fettered by the same kind of regulations that protect (but also constrain) workers in other hazardous work sites. to obtain work permits on the same basis as other immigrant workers' as well as by making 'sex work amenable to the same kinds of regulations that have reduced harm to workers in... other sometimes hazardous work sites' (Alexander, 1997: 93). However, this overlooks the complex and variable ways in which those who trade sex position themselves in relation to 'prostitution'. At present, much sex commerce takes place in an unregulated underground, or an 'economy of makeshifts' that stands outside civil society understood as 'a social, cultural and ethical system made up of the market, the legal system and voluntary associations to promote the welfare of the community' (Brace, 2002: 334). This is certainly one of the reasons why prostitution is stigmatised, but it is also one of the reasons why those who are excluded from civil society - including undocumented migrants, as well as runaway teenagers, drug addicts, and so on often turn to it as a means of survival. And it is by no means clear that they would wish to be incorporated into civil society as a 'sex worker', even if this option was open to them. ${ }^{3}$

More generally, there is little cause for confidence in the state as an ally in any struggle to protect the rights of those who trade sex (Chapkis, 1997; 0'Connell Davidson, 2003). And yet decriminalization without state regulation, a policy approach advocated by some feminists and prostitute activists, is hardly an attractive alternative, since it endorses 'the sort of minimal regulation on industry that even Milton Friedman would approve' (Shrage, 1994: 83). I do not, then, believe that there is a single, neat and easy policy response to prostitution that will protect all those who trade sex. However, I do believe that policy debate on forced labour in the sex sector cannot be bracketed off from debate on the more general regulation of that sector, any more than the issue of 'trafficking' can be treated in isolation from the more general phenomenon of migration.

In the absence of debate on the specificity of sex work, the details of labour regulation, and the minimum standards that should be applied to the work of prostitutes, and on what constitutes an unacceptable level of 'exploitation' within prostitution (self-exploitation as well as by an employer), it is dangerous to talk about forced prostitution and sex slaves. For without some agreement on the standards and norms that should apply, it is impossible to say which side of the line separating forced labour from extremely poor working conditions women like those working for Pat fall on, and therefore impossible either to take steps to assist them as victims of forced labour, or to identify strategies for improving their situation as 'free' workers undertaking 'poor work'. If we cannot, for example, identify a maximum number of clients per day that a sex worker can be expected to service, a minimum payment per sexual service provided, a maximum number of times that a sex worker can safely agree to provide anal sex, and minimum standards with regard to other health and safety issues specifically associated with sex work, then there is no way of 
distinguishing between the three employers described earlier except through reference to the use of physical force.

In the UK, the current immigration regime and the absence of labour standards in the sex sector combine to leave many irregular migrants in a position whereby they have little choice but to accept extremely poor working conditions and highly exploitative employment relations. They can expect (in theory if not in practice) nothing more from the state than to be protected from an employer who locks them into a building, and/or rapes or beats them or threatens to kill their family. Such a very low standard of nothingness effectively equips employers with a carte blanche to make whatever contracts they please with sex workers, and perhaps the most remarkable thing about the sex industry is the fact that there are actually some employers, like Ava, who attempt to raise the standard beyond the extraordinarily basic minimum requirement that they should not use physical force against their employees. Far from representing a step forward in terms of securing rights and protections for those who are subject to exploitative employment relations and poor working conditions in the trade sex, the current policy emphasis on sex slaves and VoTs limits the state's obligations towards them.

\section{acknowledgements}

I am grateful to the Economic and Social Research Council, which funded the research on which this paper is based (Award No. R000239794), and to Bridget Anderson, who co-holds this award and with whom the ideas presented in this paper have been developed.

\section{author biography}

Julia O'Connell Davidson is Professor of Sociology at the University of Nottingham. She has been involved in research on various aspects of the commercial sex trade since 1993, and is currently working on an ESRC-funded project exploring the markets for migrant sex and domestic workers in the UK and Spain. She is the author of Prostitution, Power \& Freedom (Polity, 1998) and Children in the Global Sex Trade (Polity, 2005).

\section{references}

Agustín, L. (2002) 'Challenging 'place': leaving home for sex' Development, Vol. 45, No. 1: 110-116.

Agustín, L. (2005) 'Migrants in the Mistress's house: other voices in the 'trafficking' debate' Social Politics, Vol. 12, No. 1: 96-117.

Alexander, P. (1997) 'Feminism, sex workers and human rights' in J. Nagel, editor, Whores and Other Feminists, London: Routledge.

AMC (2000) Asian Migrant Yearbook 2000: Migration Facts, Analysis and Issues in 1999, Hong Kong: Asian Migrant Centre. 
Anderson, B. and O'Connell Davidson, J. (2002) Trafficking - A Demand Led Problem? Part I, Stockholm: Save the Children Sweden.

Anderson, B. and Rogaly, B. (2005) Free Market, Forced Labour?, London: TUC.

Andrijasevic, R. (2003) 'The difference borders make: (il)legality, migration and 'trafficking' in Italy among 'eastern' European women in prostitution' in S. Ahmed, C. Castaneda, A. Fortier and M. Sheller, editors, Uprootings/Regroundings: Questions of Home and Migration, Berg.

AntiSlavery International (2005) Trafficking Network Update, January. London: ASI.

Aradau, C. (2004) 'The perverse politics of four-letter words: risk and pity in the securitisation of human trafficking' Journal of International Studies, Vol. 33, No. 2: 251-277.

Bales, K. (2000) Disposable People: New Slavery in the Global Economy, Berkeley, CA: University of California Press.

Barry, K. (1995) The Prostitution of Sexuality, Ny: New York University Press.

Beare, M. (1999) 'Illegal migration: personal tragedies, social problems, or national security threats?', in P. Williams, editor, Illegal Immigration and Commercial Sex: The New Slave Trade, London: Frank Cass.

Beckles, H. (1989) Natural Rebels: A Social History of Enslaved Black Women in Barbados, Bloomington: Indiana University Press.

Bindman, J. (1997) Redefining Prostitution as Sex Work on the International Agenda, London: Anti-Slavery International.

Blackett, A. (1998) Making Domestic Work Visible: The Case for Specific Regulation, Geneva: International Labour Office.

Brace, L. (2002) 'The tragedy of the freelance hustler: Hegel, gender and civil society' Contemporary Political Theory, Vol. 1: 329-347.

Brace, L. (2004) The Politics of Property: Freedom and Belonging, Edinburgh: Edinburgh University Press.

Chapkis, W. (1997) Live Sex Acts, London: Cassell.

Chapkis, W. (2005) 'Soft glove, punishing fist: the Trafficking Victims Protection Act of 2000' in: $\varepsilon$. Bernstein and L. Schaffner, editors, Regulating Sex, London: Routledge.

Cowan, R. (2005) 'Immigrants tell of forced prostitution and slavery as trafficking gang is jailed' The Guardian, November 2.

Doezema, J. (1999) 'Loose women or lost women? The re-emergence of the myth of 'white slavery' in contemporary discourses of trafficking in women' Gender Issues, Vol. 18, No. 1: 23-50.

Doezema, J. (2002) 'Who gets to choose? Coercion, consent, and the UN Trafficking Protocol' in R. Masika, editor, Gender, Trafficking and Slavery, Oxford: Oxfam.

European Commission (2004) Report of the Experts Group on Trafficking in Human Beings, Brussels: European Commission.

Geary, D. (2004) 'Europe and slave protests in the Americas (1780-1850)' Mitteilungsblatt des Instituts fuer Soziale Bewegungen, Heft 31. Bochum: Ruhr University.

Harrington, C. (2005) 'The politics of rescue: Peacekeeping and anti-trafficking programs in Bosnia-Herzegovina and Kosovo' International Feminist Journal of Politics, Vol. 7, No. 2: 175-206.

Home Office (2004) Paying the Price: A consultation paper on prostitution, London: Home Office.

Home Office (2005) A Coordinated Prostitution Strategy and a Summary of Responses to Paying the Price, London: Home Office.

Hughes, D. (2000) 'Men create the demand, women are the supply' Feminista!, Vol. 4, No. 3.

ILO (2005) A Global Alliance Against Forced Labour, Geneva: International Labour Office.

Javate de Dios, A. (2002) 'Revisiting the issue of trafficking in women: Comments on policy implications of a gender and rights framework. Paper presented to ASEM Seminar, Promoting 
Gender Equality to Combat Trafficking in Women and Children, organised by the Swedish Ministry for Foreign Affairs. Bangkok, 7-9 October.

Jeffreys, S. (1997) The Idea of Prostitution, Melbourne: Spinifex.

Kapur, R. (2005) Erotic Justice: Law and The New Politics of Postcolonialism, London: Glasshouse.

Kelly, L. and Regan, L. (2000) 'Stopping traffic: Exploring the extent of and responses to trafficking in women for sexual exploitation in the UK' Police Research Series, Paper 125. London: Home Office.

Kempadoo, K. (1999) 'Slavery or work? Reconceptualising Third World prostitution' Positions, Vol. 7, No. 1: 225-237.

Kempadoo, K. and Doezema, J. (1998) Global sex workers: Rights, Resistance and Redefinition, New York: Routledge.

King, R. (2002) 'Towards a new map of European migration' International Journal of Population Geography, Vol. 8: 89-106.

Lim, L. (1998) The Sex Sector: The Economic and Social Bases of Prostitution in Southeast Asia, Geneva: International Labour Office.

Lott, T. (1998) 'Early Enlightenment conceptions of the rights of slaves' in T. Lott, editor, Subjugation and Bondage, Rowman and Littlefield.

Lutz, H. (2004) 'Life in the twilight zone: migration, transnationality and gender in the private household' Journal of Contemporary European Studies, Vol. 12, No. 1: 47-55.

Nagle, J. (1997) Whores and Other Feminists, London: Routledge.

O'Connell Davidson, J. (2003) 'Sleeping with the enemy? Some problems with feminist abolitionist calls to penalise those who buy commercial sex' Social Policy \& Society, Vol. 2, No. 1: 55-63.

O’Connell Davidson, J. (2005) Children in the Global Sex Trade, Cambridge: Polity.

Parrenas, R. (2001) Servants of Globalization: Women, Migration and Domestic Work, Stanford, CA: Stanford University Press.

Patterson, 0. (1982) Slavery and Social Death, Cambridge, MA: Harvard University Press.

Pearson, $\boldsymbol{\varepsilon}$. (2002) Human Traffic, Human Rights: Redefining victim protection, London: AntiSlavery International.

Raymond, J. (2001) Guide to the New UN Trafficking Protocol, North Amherst, MA: CATW.

Shrage, L. (1994) Moral Dilemmas of Feminism, London: Routledge.

Weitzer, R. (2005) 'Flawed theory and method in studies of prostitution' Violence Against Women, Vol. 11, No. 7: 934-949.

doi:10.1057/palgrave.fr. 9400278 